\title{
Faktor yang Memengaruhi Perilaku Penggunaan Air Bersih pada Masyarakat Kumuh Perkotaan berdasar atas Integrated Behavior Model
}

\author{
Ardini S. Raksanagara, ${ }^{1}$ Ayu Mutiara Santanu, ${ }^{2}$ Sri Yusnita Irda Sari, ${ }^{1}$ \\ Deni K. Sunjaya, ${ }^{1}$ Insi Farisya Deasy Arya, ${ }^{1}$ Dwi Agustian ${ }^{1}$ \\ ${ }^{1}$ Departemen Ilmu Kesehatan Masyarakat Fakultas Kedokteran Universitas Padjadjaran \\ ${ }^{2}$ Program Magister Ilmu Kesehatan Masyarakat Fakultas Kedokteran Universitas Padjadjaran
}

\begin{abstract}
Abstrak
Kebutuhan air bersih semakin meningkat terutama di wilayah perkotaan. Kelurahan Tamansari merupakan wilayah kumuh yang berlokasi di tengah Kota Bandung, 60\% penduduk menggunakan air bersih perpipaan sisanya menggunakan sumber air tanah, namun tidak semua sumber air dilindungi secara benar sehingga berpotensi terkontaminasi. Penelitian ini bertujuan menganalisis faktor yang memengaruhi perilaku penggunaan air bersih pada masyarakat kumuh perkotaan dengan mengaplikasikan teori Integrated Behavior Model. Penelitian potong lintang dilakukan pada 188 rumah tangga di 10 RW pada bantaran sungai Cikapundung di Kelurahan Tamansari. Survei dilakukan menggunakan kuesioner dan ceklist observasi pada sumber air perpipaan (PDAM), sumur terlindungi (ST), dan sumur tidak terlindungi (STT). Hasil penelitian menunjukkan sikap, norma yang dipersepsikan dan faktor personal memengaruhi niat untuk menggunakan air bersih pada ketiga jenis sumber air yang digunakan. Pada pengguna PDAM tidak ada faktor yang signifikan memengaruhi perilaku. Pada pengguna ST perilaku dipengaruhi oleh faktor kepentingan menggunakan air bersih. Pada pengguna STT faktor niat, hambatan lingkungan dan kebiasaan memengaruhi perilaku menggunakan air bersih. Faktor-faktor yang memengaruhi perilaku khususnya di wilayah kumuh perkotaan berbeda-beda berdasar atas sumber air bersih yang digunakan sehingga upaya promosi kesehatan untuk melakukan perubahan perilaku harus dikembangkan sesuai dengan jenis sumber air yang digunakan. [MKB. 2017;49(2):122-31]
\end{abstract}

Kata kunci: Air bersih, integrated behavior model , kumuh perkotaan, perilaku

\section{Integrated Behavior Model: Factors Influencing Clean Water Use among Urban Slum Dwellers}

\begin{abstract}
The increasing need for clean water, especially in urban area, is becoming more prominent. Tamansari Urban Village is a slum area located in the center of Bandung City. Sixty percents of its dwellers use pipe water as the clean water source while the rest uses ground water. However, not all water sources are protected correctly that there is a potential for contamination. This study aimed to analyze factors influencing clean water use behavior among urban slum dwellers by applying the Integrated Behavior Model. A cross-sectional study was performed on 188 households in 10 RW (neighborhood unit) on Cikapundung River Bank in Taman Sari Urban Village. Questionnaires and observation checklists were used for piping water source (Local Water Company, PDAM), protected wells, and unprotected wells. The results of this study showed that the attitude, perceived norms, and personal factors influenced the intention to use clean water for the three clean water sources. Among PDAM users, no significant factor was seen to influence behavior. Among protected well users, the behavior was influenced by the interest factor in using clean water. Among unprotected well users, attitude, environmental barriers, and habit influenced the behavior of using clean water. Factors influencing behaviors, especially in urban slum areas, are different based on the source of clean water used; hence, the implementation health promotion through behavioural change should be adapted to the type of water source used. [MKB. 2017;49(2):122-31]
\end{abstract}

Key words: Behavior, clean water, integrated behavior model, urban slum

Korespondensi: Dr. Ardini S. Raksanagara, dr., MPH, Departemen Ilmu Kesehatan Masyarakat Fakultas Kedokteran Universitas Padjadjaran, Jalan Prof. Eyckman No. 38 Bandung, E-mail: araksanagara@yahoo.com 


\section{Pendahuluan}

Saat ini diperkirakan sekitar 1,1 miliar penduduk belum memiliki akses air minum yang aman sejak tahun 2002 sehingga 6.500 anak setiap hari meninggal akibat diare. ${ }^{1}$ Secara umum kematian akibat diare pada anak di dunia mencapai 42.000 kasus/minggu, 6.000 kasus/hari, 4 kasus/menit, dan 1 kematian/14 detik. ${ }^{2}$ Jumlah penduduk perkotaan meningkat tajam terutama di negaranegara berkembang akibat urbanisasi yang cepat, hal ini banyak menciptakan daerah yang kumuh dan minim akses air bersih. ${ }^{3}$

Survei Demografi Kesehatan Indonesia telah memperlihatkan prevalensi diare balita akibat minimnya akses air bersih di Indonesia tercatat $11 \%$ dengan prevalensi tertinggi di Provinsi Sulawesi Selatan 15,50\% dan Jawa Barat 15,10\%. ${ }^{4}$ Wilayah dengan estimasi jumlah penderita diare yang diobati berdasar atas data dari Dinas Kesehatan Kota Bandung menunjukkan meningkat hampir 200\% terutama terdapat di Kecamatan Mandalajati, Panyileukan, dan Bandung Wetan. ${ }^{5}$

Kelurahan Tamansari merupakan wilayah kumuh di Kecamatan Bandung Wetan yang berada tengah Kota Bandung di bantaran sungai Cikapundung. Wilayah ini merupakan model wilayah kumuh percontohan dengan data penderita diare balita terbanyak sehingga menjadi area perbaikan pembangunan dan penelitian mengenai kesehatan. Sebagian besar (82\%) jamban tidak memiliki tangki septik sehingga limbah rumah tangga langsung mengalir ke sungai dan berisiko tinggi mencemari sumber air warga. ${ }^{6}$

Sebagian besar masyarakat mempunyai akses air bersih dari air perpipaan bersumberkan PDAM, namun hanya $13,33 \%$ dari 210 sampel menunjukkan kualitas yang baik. $^{7}$ Sebagian masyarakat masih mempergunakan sumber air tanah berupa sumur terlindung (ST) seperti sumur bor, sumur gali tertutup dengan pompa dan sumur tidak terlindung (STT) seperti sumur gali yang terbuka dan mata air yang sangat rentan terkontaminasi.

Perilaku masyarakat dalam menentukan pilihan sumber air bersih dapat dipengaruhi oleh beberapa faktor yang berbeda-beda. Pada penduduk di Kelurahan Tamansari tidak semua memilih air perpipaan walaupun jaringan distribusi air PDAM tersedia, sebagian penduduk masih mengandalkan sumber air tanah yang lebih berisiko terkontaminasi dikarenakan masih banyak perilaku masyarakat yang belum menggunakan jamban sehat. Penduduk yang menggunakan sumber air sumur masih banyak yang belum memperhatikan syarat pembuatan sumur yang baik sehingga sebagian masih merupakan STT.

Integrated Behavioral Model (IBM) merupakan teori perilaku kesehatan yang berfokus pada individu yang merupakan sasaran paling penting dalam perubahan perilaku yang diharapkan sehingga informasi mengenai peran individu dalam perubahan perilaku sangat diperlukan untuk menyusun rencana intervensi. IBM menekankan pentingnya niat sebagai motivasi untuk berperilaku. Perilaku tertentu paling mungkin terjadi jika seseorang memiliki niat kuat untuk melakukan, memiliki pengetahuan serta keterampilan untuk melakukannya, tidak ada kendala lingkungan yang serius menghalangi, perilaku tersebut diyakini penting, dan orang tersebut telah melakukan perilaku sebelumnya sebagai kebiasaan. ${ }^{8}$ Niat sebagai faktor paling penting ditentukan oleh sikap terhadap perilaku, norma yang dipersepsikan, dan faktor personal. Perilaku mempergunakan air bersih menjadi dasar penilaian pada faktor-faktor perilaku hidup bersih sehat di rumah tangga. Faktor penentu perilaku digunakan untuk memahami perilaku dan menentukan strategi intervensi untuk menghasilkan perubahan perilaku yang diharapkan.

Penelitian ini bertujuan mengetahui faktorfaktor apa yang paling dominan memengaruhi perilaku terhadap penggunaan sumber air bersih khususnya pada masyarakat kumuh perkotaan, teori yang paling sesuai untuk dapat diaplikasikan adalah teori IBM karena teori ini mengintegrasikan antara pengaruh internal individu dan pengaruh hambatan lingkungan. Hasil penelitian ini juga diharapkan mampu meningkatkan upaya intervensi dalam program pencegahan penyakit menular khususnya dalam upaya mengembangkan promosi kesehatan yang tepat dalam penggunaan air bersih.

\section{Metode}

Penelitian ini menggunakan rancangan potong lintang, variabel bebas terdiri atas variabel pengetahuan (knowledge), kepentingan terhadap perilaku (sallience of the behavior), niat untuk menerapkan perilaku (intention to perform the behavior), hambatan lingkungan (environmental constraints), dan kebiasaan (habits). Variabel terikat adalah perilaku dalam penggunaan air bersih dengan tiga jenis sumber air bersih, yaitu PDAM, ST, dan STT. 
Subjek penelitian ini adalah semua rumah tangga yang berada di 10 RW wilayah bantaran sungai Cikapundung Kelurahan Tamansari, Kecamatan Bandung Wetan, Kota Bandung. Sampel penelitian ditentukan dengan metode acak sederhana, yaitu dengan cara membuat daftar seluruh rumah di ke-10 RW yang telah terpilih sebanyak 1.740 rumah, kemudian dibuat tabel angka acak dengan menggunakan software dari www.randomization.com sehingga dihasilkan daftar rumah yang menjadi unit sampel. Sumber air bersih yang digunakan pada beberapa rumah dapat terdiri lebih dari satu sumber air. Responden dibagi berdasar atas sumber air bersih yang digunakan dengan total 188 rumah, yaitu 89 responden yang memiliki sumber air dari PDAM, 72 responden ST, dan 27 responden STT.

Responden merupakan anggota rumah tangga yang mengetahui mengenai pemakaian air bersih di rumah tersebut. Data diambil melalui kuesioner yang telah diuji validitas dan reliabilitasnya, serta ceklist observasi yang diadopsi dari pedoman WHO. Data dianalisis dengan multivariat confirmatory factor analysis menggunakan software $R$-study, selanjutnya dilakukan analisis regresi linier berganda. Setiap responden penelitian sudah menerima informasi lengkap mengenai penelitian ini dan menandatangani lembar persetujuan sebelum dilakukan pengambilan data. Persetujuan etik diperoleh dari Komite Etik Fakultas Kedokteran Universitas Padjadjaran No: 314/UN6.C1.3.2/ KEPK/PN/2015.

\section{Hasil}

Kelurahan Tamansari merupakan kawasan pemukiman kumuh dan juga kepadatan tinggi dengan jumlah penduduk sebanyak 28.729 jiwa. Penduduk menggunakan berbagai macam sumber air bersih, yaitu air yang digunakan untuk keperluan sehari-hari seperti cuci, mandi, dan sebagai sumber air untuk memdapatkan air minum dengan persyaratan jumlah bakteri Coliform kurang dari $1.000 / \mathrm{mL}$. Sebagian penduduk menggunakan air bersih perpipaan yang bersumber dari PDAM walaupun terdapat distribusi jaringan pipa PDAM di wilayah kelurahan Tamansari, hal ini disebabkan oleh air PDAM tidak mengalir setiap hari selama 24 jam, air PDAM lebih sering hanya mengalir pada malam hari selama 3-4 jam saja. Sebagian penduduk lainnya masih menggantungkan pada sumber air tanah seperti air sumur dan mata air, selain karena mudah didapatkan juga lebih murah biayanya. Sumur yang digunakan masyarakat sebagian merupakan sumur terlindungi (ST), namun masih banyak juga yang merupakan sumur tidak terlindungi (STT) yang berisiko tinggi untuk terkontaminasi, penduduk dengan air bersih dari STT ini sangat dimungkinkan dikarenakan pengetahuan yang rendah akan pentingnya air bersih yang berkualitas dan bagaimana persyaratan pembuatan sumur yang standar.

Karakteristik dari responden juga berbedabeda berdasar atas jenis sumber air yang digunakannya seperti yang dijelaskan pada Tabel 1. Sebagian besar responden PDAM dan ST bekerja wiraswasta/layanan jasa/dagang dan mayoritas tamat SMA, sedangkan responden STT sebagian besar mempunyai pekerjaan buruh atau lainnya dan pendidikan tamat SD dan SMA sama banyak. Responden PDAM mempunyai pengeluaran paling besar. Responden ST umumnya memakai air dengan jumlah terbanyak per hari semua responden umumnya melakukan pengolahan air minum dengan cara dimasak. Presentasi terbesar kedua adalah konsumsi air minum tanpa diolah, yaitu air minum isi ulang sehingga semua responden memakai dispenser. Pengguna PDAM sebanyak 60,7\% menyatakan harus melakukan pengendapan sebelum akan digunakan.

Tabel 2 memperlihatkan skor pengetahuan, sikap, norma, kepentingan penggunaan air bersih dan niat responden yang paling besar adalah responden PDAM yang termasuk kategori baik. Tabel 3 menunjukkan tingkat risiko sumber air bersih termasuk kategori sedang (56\%). Skor hambatan lingkungan dan kebiasaan responden yang paling besar adalah responden ST yang termasuk kategori tinggi dan Tabel 3 menunjukkan tingkat risiko sumber air bersih termasuk kategori sedang (50\%). Skor faktor personal yang paling besar adalah responden STT yang termasuk kategori baik, namun Tabel 3 menunjukkan tingkat risiko sumber air bersih termasuk kategori tinggi (74\%).

Tabel 3 menunjukkan perilaku menggunakan air bersih berbeda pada ketiga kelompok responden berdasar atas jenis sumber air bersih yang digunakan. Pada responden PDAM dan ST termasuk perilaku dengan kategori cukup dan responden STT termasuk perilaku dengan kategori buruk. Gambar 1, 2, dan 3 menunjukkan tiap-tiap faktor mempunyai pengaruh yang berbeda-beda terhadap perilaku penggunaan air bersih.

Pada pengguna PDAM seperti yang dijelaskan 
Ardini S. Raksanagara: Faktor yang Memengaruhi Perilaku Penggunaan Air Bersih pada Masyarakat Kumuh Perkotaan

Tabel 1 Karakteristik Responden berdasarkan Sumber Air Bersih

\begin{tabular}{|c|c|c|c|}
\hline Karakteristik & $\begin{array}{l}\text { PDAM } \\
\text { n (\%) }\end{array}$ & $\begin{array}{c}\text { ST } \\
\text { n (\%) }\end{array}$ & $\begin{array}{c}\text { STT } \\
\text { n (\%) }\end{array}$ \\
\hline \multicolumn{4}{|l|}{ Pekerjaan Kepala Keluarga } \\
\hline Tidak Bekerja & $25(28)$ & $14(19)$ & $2(7)$ \\
\hline PNS/Pegawai & $1(1)$ & $2(3)$ & $3(11)$ \\
\hline Wiraswasta & $40(45)$ & $40(56)$ & $7(26)$ \\
\hline Buruh & $5(6)$ & $5(7)$ & $6(22)$ \\
\hline Lainnya & $18(20)$ & $11(15)$ & $9(33)$ \\
\hline \multicolumn{4}{|l|}{ Pendidikan Kepala Keluarga } \\
\hline Tidak Tamat SD & $1(1)$ & $2(3)$ & 0 \\
\hline Tamat SD & $19(21)$ & $20(28)$ & $9(33)$ \\
\hline Tamat SMP & $11(12)$, & $5(7)$ & $6(22)$ \\
\hline Tamat SMA & $39(44)$ & $33(46)$ & $9(33)$ \\
\hline Tamat PT & $15(17)$ & $9(12)$ & $1(4 \%)$ \\
\hline Lainnya & $4(4)$ & $3(4)$ & $2(7 \%)$ \\
\hline Tidak Tamat SD & $1(1)$ & $2(3)$ & 0 \\
\hline \multicolumn{4}{|l|}{ Jumlah anggota keluarga } \\
\hline Median (SD) & $4(2)$ & $5(3)$ & $5(3)$ \\
\hline Minimal-Maksimal & $1-9$ & $1-23$ & $2-14$ \\
\hline \multicolumn{4}{|l|}{ Jumlah balita } \\
\hline Median (SD) & $0(1)$ & $0(1)$ & $0(1)$ \\
\hline Minimal-Maksimal & $0-2$ & $0-3$ & $0-3$ \\
\hline \multicolumn{4}{|l|}{ Pengeluaran per Bulan (Rp) } \\
\hline Median (SD) & $\begin{array}{c}\mathbf{4 . 4 8 1 . 2 0 1} \\
(2.185 .871)\end{array}$ & $\begin{array}{c}3.626 .192 \\
(\mathbf{5 . 2 9 4 . 2 7 4 )}\end{array}$ & $\begin{array}{c}2.913 .854 \\
1.582 .653)\end{array}$ \\
\hline \multicolumn{4}{|c|}{ Jumlah pemakaian air bersih per hari (liter) } \\
\hline Median (SD) & $327(225)$ & $436(428)$ & $312(211)$ \\
\hline \multicolumn{4}{|l|}{ Sumber air minum } \\
\hline PDAM & $28(31)$ & $4(6)$ & $3(11)$ \\
\hline ST & $3(3)$ & $18(25)$ & 0 \\
\hline STT & $2(1)$ & 0 & $3(11)$ \\
\hline Kemasan & $27(30)$ & $21(29)$ & $6(22)$ \\
\hline Isi Ulang & $30(34)$ & $27(37)$ & $15(56)$ \\
\hline Lain-lain & $1(1)$ & $2(3)$ & 0 \\
\hline \multicolumn{4}{|c|}{ Jumlah pemakaian air minum per hari (liter) } \\
\hline Median (SD) & $15(32)$ & $59(386)$ & $8(6)$ \\
\hline Minimal-Maksimal & $2-200$ & $1-3167$ & $2-30$ \\
\hline \multicolumn{4}{|l|}{ Pengolahan air minum } \\
\hline Dimasak & $61(69)$ & $45(62)$ & $18(67)$ \\
\hline UV & 0 & $1(1)$ & 0 \\
\hline Klonirasi & 0 & $1(1)$ & 0 \\
\hline Tidak di olah & $24(27)$ & $25(35)$ & $9(33)$ \\
\hline
\end{tabular}


Ardini S. Raksanagara: Faktor yang Memengaruhi Perilaku Penggunaan Air Bersih pada Masyarakat Kumuh Perkotaan

Lainnya

Penyimpanan air minum

Dispenser

Teko

Kendi

Ember Tertutup

Lainnya

Pengendapan

Ya

Tidak
$4(4)$

49(55)

34 (38)

2 (2)

1 (1)

3 (3)

54(61)

$35(39)$
0

0

$\begin{array}{cc}43(60) & 18(67) \\ 24(33) & 8(30) \\ 0 & 0 \\ 2(2,78 \%) & 0 \\ 3(4) & 1(4)\end{array}$

$33(46)$

14 (52)

$39(54)$

$13(48$,

Tabel 2 Distribusi Variabel Berdasarkan Sumber Air Bersih

\begin{tabular}{|c|c|c|c|}
\hline Variabel & $\begin{array}{c}\text { PDAM } \\
\text { (89 Responden) }\end{array}$ & $\begin{array}{c}\text { ST } \\
\text { (72 Responden) }\end{array}$ & $\begin{array}{c}\text { STT } \\
\text { (27 Responden) }\end{array}$ \\
\hline \multicolumn{4}{|l|}{ Pengetahuan } \\
\hline Rata-rata (SD) & $8,10(1,23)$ & $8,04(1,36)$ & $7,70(1,30)$ \\
\hline Minimal-Maksimal & $5-10$ & $3-10$ & $5-10$ \\
\hline \multicolumn{4}{|c|}{ Kepentingan penggunaan air bersih } \\
\hline Rata-rata (SD) & $16,66(1,71)$ & $16,49(2,34)$ & $16,44(2,38)$ \\
\hline Minimal-Maksimal & $10-18$ & $9-18$ & $9-18$ \\
\hline \multicolumn{4}{|c|}{ Niat untuk menggunakan air bersih } \\
\hline Rata-rata (SD) & $72,87(6,36)$ & $72,69(7,12)$ & $71,67(6,65)$ \\
\hline Minimal-Maksimal & $60-86$ & $50-85$ & $57-84$ \\
\hline \multicolumn{4}{|l|}{ Hambatan lingkungan } \\
\hline Rata-rata (SD) & $28,66(5,29)$ & $30,76(4,35)$ & $30,30(6,68)$ \\
\hline Minimal-Maksimal & $14-36$ & $19-36$ & $16-36$ \\
\hline \multicolumn{4}{|l|}{ Kebiasaan } \\
\hline Rata-rata (SD) & $3,54(1,07)$ & $3,69(1,22)$ & $3,19(1,00)$ \\
\hline Minimal-Maksimal & $1-5$ & $1-5$ & $1-5$ \\
\hline \multicolumn{4}{|c|}{ Norma yang dipersepsikan } \\
\hline Rata-rata (SD) & $21,21(2,59)$ & $20,97(3,31)$ & $21,00(3,82)$ \\
\hline Minimal-Maksimal & $14-24$ & $12-24$ & $11-24$ \\
\hline \multicolumn{4}{|l|}{ Faktor personal } \\
\hline Rata-rata (SD) & $10,34(1,94)$ & $10,43(1,91)$ & $10,67(1,64)$ \\
\hline Minimal-Maksimal & $3-12$ & $5-12$ & $7-12$ \\
\hline \multicolumn{4}{|l|}{ Sikap } \\
\hline Rata-rata (SD) & $41,31(3,83)$ & $41,29(3,62)$ & $40,00(3,72)$ \\
\hline Minimal-Maksimal & $34-50$ & $32-49$ & $34-48$ \\
\hline \multicolumn{4}{|c|}{ Perilaku menggunakan air bersih } \\
\hline Rata-rata (SD) & $2,82(1,36)$ & $3,57(1,86)$ & $6,74(1,72)$ \\
\hline Minimal-Maksimal & $0-6$ & $0-7$ & $2-10$ \\
\hline
\end{tabular}


Ardini S. Raksanagara: Faktor yang Memengaruhi Perilaku Penggunaan Air Bersih pada Masyarakat Kumuh Perkotaan

Tabel 3 Tingkat Risiko Sumber Air Bersih berdasar atas Inspeksi Sanitasi

\begin{tabular}{lccc}
\hline \multicolumn{1}{c}{ Tingkat Risiko } & PDAM $(\mathbf{n}=\mathbf{8 9})$ & ST $(\mathbf{n = 7 2 )}$ & STT (n=27) \\
\hline Risiko sangat tinggi & 0 & 0 & $2(7)$ \\
Risiko tinggi & $2(2)$ & $12(17)$ & $20(74)$ \\
Risiko sedang & $48(56)$ & $36(50)$ & $4(15)$ \\
Risiko rendah & $36(42)$ & $24(33)$ & $1(4)$ \\
\hline
\end{tabular}

pada Gambar 1, faktor yang menunjukkan hubungan yang berlawanan arah adalah faktor sikap dan norma terhadap niat, begitu pula dengan faktor pengetahuan, kepentingan para penggunaan air bersih, hambatan lingkungan, dan kebiasaan terhadap perilaku penggunaan air bersih. Faktor yang menunjukkan hubungan searah adalah faktor personal terhadap niat dan niat terhadap perilaku penggunaan air bersih.

Pada pengguna ST (Gambar 2), faktor yang menunjukkan hubungan yang berlawanan arah adalah faktor sikap terhadap niat, serta faktor pengetahuan, kepentingan penggunaan air bersih, hambatan lingkungan, dan kebiasaan terhadap perilaku penggunaan air bersih. Faktor yang menunjukkan hubungan searah adalah norma dan faktor personal terhadap niat dan niat terhadap perilaku penggunaan air bersih.

Pada pengguna STT (Gambar 3), faktor yang memperlihatkan hubungan yang berlawanan arah adalah faktor sikap, norma dan faktor personal terhadap niat, serta faktor niat terhadap perilaku penggunaan air bersih. Faktor yang menunjukkan hubungan searah adalah pengetahuan, hambatan lingkungan, kepentingan penggunaan air bersih, dan kebiasaan terhadap perilaku penggunaan air bersih.

\section{Pembahasan}

Faktor-faktor yang memengaruhi keputusan masyarakat dalam memilih sumber air bersih yang dipergunakan dipengaruhi oleh hal yang berbeda-beda. Begitu pula dengan latar belakang karakteristik masyarakat yang berbeda-beda berdasar atas jenis sumber air bersih yang dipilihnya. Air perpipaan dan ST lebih dipilih

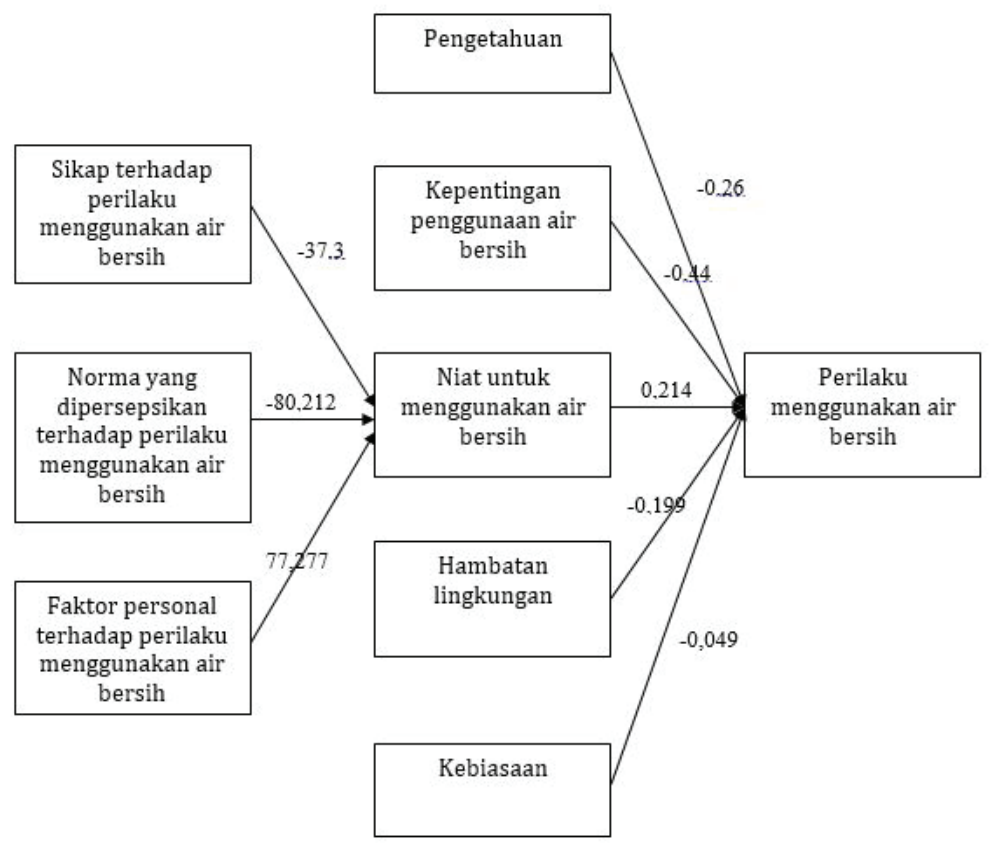

Gambar 1 Hasil Analisis Pengaruh Perilaku Penggunaan Air Bersih (PDAM) 


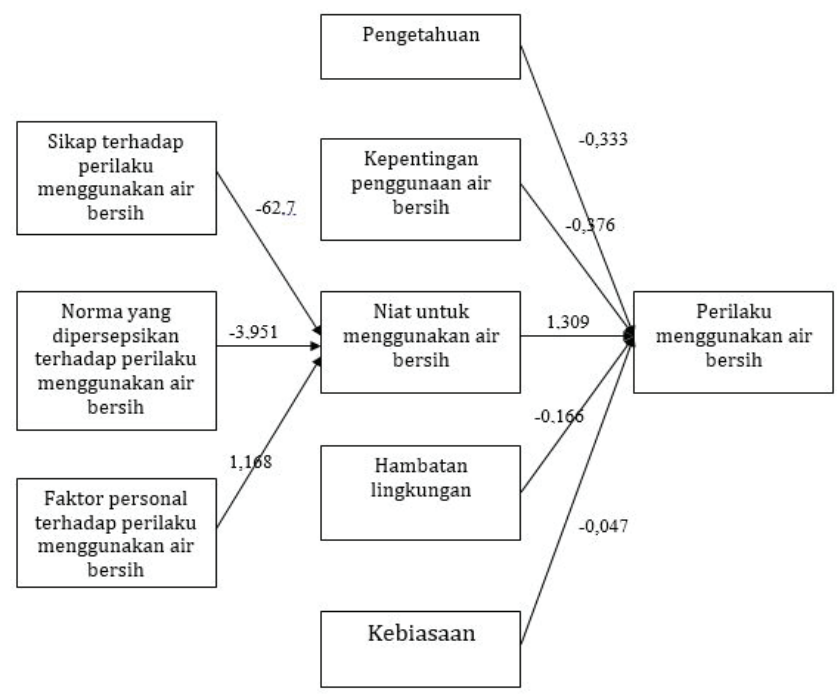

\section{Gambar 2 Hasil Analisis Pengaruh Perilaku Penggunaan Air Bersih (ST)}

oleh masyarakat dengan tingkat pendidikan dan pendapatan lebih lebih tinggi. Penduduk dengan penghasilan rendah cenderung memilih sumber air yang tidak berbayar, namun karena tingkat pendidikan yang lebih rendah mereka cenderung tidak memperhatikan atau mengabaikan syarat pembuatan sumur yang standar.

Faktor-faktor yang memengaruhi perilaku memilih sumber air bersih berdasar atas teori IBM didapatkan hasil sebagai berikut, yaitu sikap, norma yang dipersepsikan, dan faktor personal pada responden PDAM berpengaruh terhadap niat. Pada responden ST, hanya sikap yang berpengaruh dan pada responden STT hanya faktor personal yang memengaruhi niat. Sesuai penelitian di beberapa negara menunjukkan bahwa sikap dapat berpengaruh terhadap niat menmpergunakan air bersih. ${ }^{9}$ Sikap merupakan kesiapan atau kesediaan untuk bertindak dan bukan merupakan pelaksanaan motif tertentu. Sikap belum merupakan suatu tindakan atau aktivitas, akan tetapi merupakan predisposisi

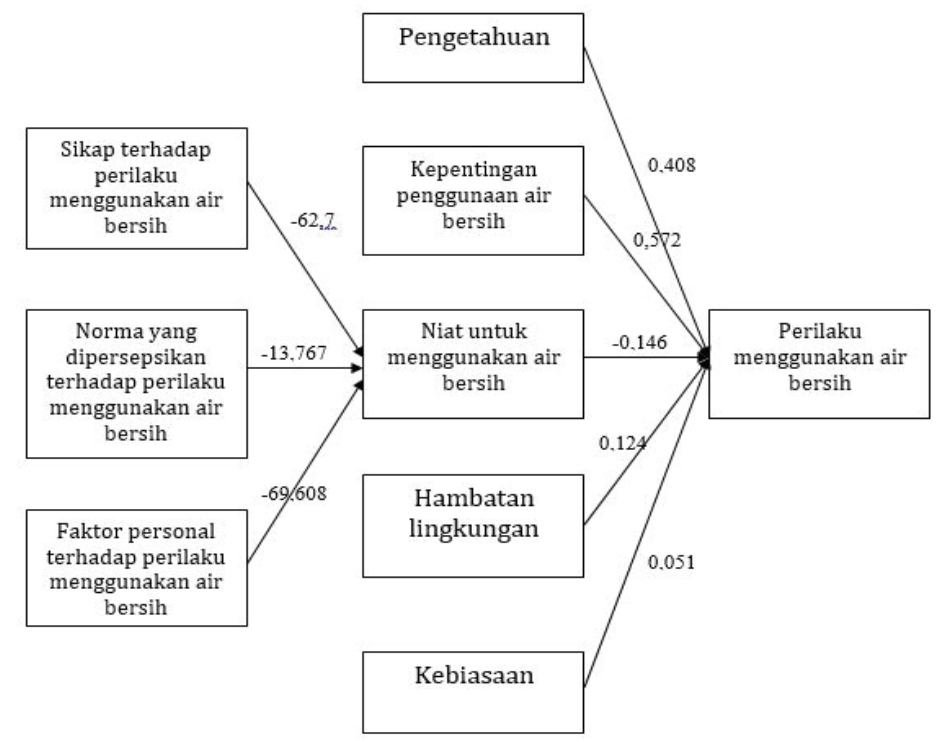

Gambar 3 Hasil Analisis Pengaruh Perilaku Penggunaan Air Bersih (STT) 
suatu perilaku. ${ }^{8}$

Variabel norma yang memengaruhi niat menggunakan air bersih pada responden PDAM yang sesuai dengan penelitian yang menunjukkan terdapat pengaruh norma yang didapat dari tekanan sosial orang lain dengan niat individu itu sendiri untuk melakukan suatu perilaku. . $^{8,10,11}$ Persepsi tentang norma didefinisikan sebagai tekanan sosial untuk menampilkan atau tidak menampilkan suatu perilaku. ${ }^{12}$ Norma subjektif adalah persepsi individu terhadap tekanan sosial yang mendorongnya untuk melaksanakan atau tidak melaksanakan suatu perilaku, ${ }^{13}$ juga menekankan pada kepercayaan dalam arti kepercayaan personal menilai individu atau kelompok untuk setuju atau tidak setuju terhadap perilaku yang akan dilakukan. ${ }^{11}$ Responden PDAM menunjukkan nilai pengaruh yang kuat dari sikap, norma yang dipersepsikan, dan faktor personal yang menunjukkan responden terpengaruh persepsi bahwa menggunakan PDAM merupakan sumber air bersih yang terbaik.

Pada responden ST, hanya sikap yang berpengaruh kuat terhadap niat menggunakan air bersih yang menunjukkan bahwa responden ST mempunyai keyakinan menggunakan sumur bor maupun sumur gali tertutup dengan pompa. Kepercayaan merupakan salah satu aspek sikap yang mempresentasikan informasi tentang perilaku yang diambil, ekspektasi normatif dari lingkungan terdekat, dan kesulitan yang dialami untuk menampilkan perilaku tersebut. ${ }^{11}$ Individu yang memiliki kepercayaan kuat tentang keuntungan menggunakan sumber air bersih ST akan memiliki sikap yang positif pula terhadap perilaku penggunaan air bersih. Responden ST beranggapan bahwa sumber air yang mereka pakai sudah baik dan menimbulkan keuntungan, misalnya keuntungan finansial.

Pada responden STT, hanya faktor personal yang berpengaruh kuat terhadap niat. Faktor personal merupakan faktor dari individu itu sendiri yang ditunjukkan oleh persepsi kontrol dan efikasi diri. Hal ini menunjukkan niat yang kuat dari dirinya sendiri untuk menggunakan STT. Faktor personal merupakan kepercayaan diri atau kemampuan untuk menampilkan suatu perilaku. Jika sikap melihat kepercayaan pada konsekuensi perilaku yang dilakukan dan kepercayaannormatifsuatukelompokdinyatakan dengan norma subjektif maka faktor personal merupakan kepercayaan terhadap sumber daya dan kesempatan untuk menampilkan perilaku. ${ }^{11}$ Sikap dan norma dinilai tidak memengaruhi niat karena responden STT kurang memiliki intensi terhadap bersih tidaknya sumber air yang mereka gunakan dan tidak peduli anggapan dari lingkungan dan orang-orang terdekat mereka yang menggunakan sumber air bersih lain untuk dikonsumsi.

Pada responden PDAM dan ST, pengetahuan, kepentingan menggunakan air bersih, niat menggunakan air yang bersih dan hambatan lingkungan dinilai juga berpengaruh, sedangkan pada kebiasaan tidak memengaruhi perilaku mempergunakan air bersih. Pada responden STT hanya niat menggunakan air bersih dan kebiasaan dinilai dapat memengaruhi perilaku menggunakan air bersih. Responden PDAM dan ST mayoritas mempunyai pekerjaan dan pendidikan yang layak, sesuai dengan penelitian yang memperlihatkan pengetahuan berpengaruh terhadap intervensi pencegahan pencemaran mikrob pada air minum rumah tangga. ${ }^{9}$

Pekerjaan dan pendidikan kepala keluarga responden PDAM dan ST yang baik serta kemampuan untuk dapat membiayai kebutuhan keluarga selama sebulan menjadi latar belakang perilaku menggunakan air bersih. Keadaan ini memengaruhi kemampuan mereka membiayai kebutuhan setiap bulannya terutama pada responden PDAM sehingga mampu memilih sumber air bersih terbaik dengan berlangganan PDAM yang dipercayai sebagai air bersih yang telah terstandar dibanding dengan menggunakan sumber air tanah yang lebih murah dari segi biaya, akan tetapi belum terjamin keamanannya. Namun, pengguna PDAM melakukan perebusan sebelum diminum jika tetap terjadi kontaminasi pada air yang mereka konsumsi, kemungkinan itu diakibatkan oleh penyimpanan air dalam wadah yang tidak baik ataupun terjadi kebocoran pada pipa PDAM sehingga air tetap terkontaminasi. Kontaminasi mikrob setelah proses pendidihan air minum dapat diakibatkan oleh air disimpan dalam wadah dengan diameter mulut yang lebar, wadah terbuka, dan air yang telah tersentuh ketika dipindahkan dari wadah. Pencemaran air minum dipengaruhi oleh penyimpanan air, risiko dari pipa saluran air, dan praktik pengelolaan air rumah tangga. ${ }^{14}$

Kepentingan penggunaan air bersih juga berpengaruh terhadap perilaku mempergunakan air bersih sesuai dengan penelitian yang menunjukkan terdapat hubungan kuat antara suatu perilaku dan kepercayaan seseorang untuk merasa penting melakukan perilaku tersebut. ${ }^{11,15,16}$ Kepentingan terhadap perilaku memakai air bersih menjadi dasar pertimbangan seseorang untuk berniat melakukan sesuatu. Jika ia menganggap apa yang akan dilakukannya 
penting maka pada tahap selanjutnya ia akan mempunyai niatyang didukung oleh sikap, norma yang dipersepsikan, dan kondisi personalnya. ${ }^{17}$

Niat dan hambatan lingkungan berpengaruh terhadap perilaku menmpergunakan air bersih di tatanan rumah tangga. ${ }^{8-10,15,16}$ Hambatan lingkungan terhadap perilaku penggunaan air bersih memiliki nilai yang baik pada semua responden. Masyarakat yang berasumsi bahwa lingkungan Tamansarimemang sudah kumuh dan air yang mereka dapat dari sumur bor maupun gali lebih mudah dan murah terjangkau. Mereka beranggapan tangki septik yang dipasang tidak begitu berpengaruh terhadap derajat kesehatan mereka sehingga dirasa tidak lagi diperlukan. Masyarakat beranggapan pemasangan tangki septik membuat polusi udara bagi warga yang rumahnya terletak dekat tangki septik komunal sehingga menimbulkan ketidaknyamanan.

Tidak terdapat pengaruh antara kebiasaan dan perilaku menggunakan air bersih pada ketiga responden sumber air, bertolak belakang dengan penelitian yang menunjukkan terdapat pengaruh antara kebiasaan dan juga perilaku penggunaan air bersih. ${ }^{16-18}$ Masyarakat merasa sumur yang mereka gunakan sudah aman karena tidak berwarna, tidak berasa, dan tidak berbau. Masyarakat juga beranggapan penyakit yang mereka alami adalah penyakit yang biasa dialami sehingga tidak menggerakkan mereka untuk mencari sumber air bersih yang lebih baik. Masyarakat terbiasa memakai sumber air yang sama dalam jangka waktu yang lama dan tidak mempunyai keinginan untuk mengganti sumber air bersih mereka karena dianggap cukup aman bahkan bagi bayi dan balita.

Sesuai klasifikasi WHO, STT terdiri atas sumur gali terbuka dan sumur gali dengan timba yang hanya tertutup sebagian..$^{19}$ Dalam penelitian ini, STT di wilayah kumuh mayoritas merupakan fasilitas umum yang tidak memenuhi syarat Permenkes. Sumur gali yang termasuk dalam STT menyediakan air yang berasal dari lapisan tanah yang relatif dekat dengan permukaan tanah sehingga mudah terkontaminasi melalui rembesan yang berasal dari tempat buangan kotoran manusia kakus/jamban dan hewan, juga dari limbah sumur itu sendiri, baik karena dinding sumur maupun saluran air limbahnya yang tidak kedap air. Hal ini tidak membuat warga ragu untuk tetap menggunakan air yang berasal dari sumur gali terbuka karena rata-rata dari mereka adalah masyarakat dengan sosial ekonomi kurang.

Hasil penelitian ini dapat disimpulkan bahwa faktor-faktor yang memengaruhi penggunaan sumber air bersih pada masyarakat kumuh perkotaan berbeda-beda berdasar atas jenis sumber air yang dipilih. Faktor sikap, norma yang dipersepsikan dan faktor personal berpengaruh terhadap niat pada responden dengan sumber air PDAM. Pada responden dengan sumber air ST hanya sikap yang berpengaruh dan pada responden dengan sumber air STT hanya faktor personal yang memengaruhi niat menggunakan air bersih. Pengaruh faktor pengetahuan, kepentingan mempergunakan air bersih, niat mempergunakan air bersih, serta hambatan lingkungan dinilai berpengaruh, sedangkan kebiasaan dinilai tidak memengaruhi perilaku menggunakan air bersih pada responden dengan sumber air bersih PDAM dan ST. Namun, pada responden dengan sumber air bersih STT, hanya niat menggunakan air bersih dan kebiasaan yang dinilai berpengaruh terhadap perilaku menggunakan air bersih.

Pembinaan berkelanjutan sangat perlu dilakukan oleh Puskesmas dan juga Dinas Kesehatan dengan memerhatikan faktor yang memengaruhinya terutama pada faktor individu, masyarakat, serta lingkungan sehingga dapat terjadi perubahan pada perilaku masyarakat walaupun membutuhkan waktu yang tidak sebentar. Peningkatan pengetahuan masyarakat dapat dilakukan dengan pemberian penyuluhan secara berkesinambungan dengan menggunakan media promosi yang bervariasi baik penyuluhan individu, berkelompok atau melalui media masa. Penyuluhan kepada masyarakat tidak hanya difokuskan pada kelompok dewasa, namun dapat juga dilakukan pada kelompok remaja dan anak-anak usia sekolah. Sebagai salah satu cara dalam mengubah sikap dan niat masyarakat adalah dengan lebih mengintensifkan kegiatan pemicuan yang merupakan salah satu bentuk sanitasi total berbasis masyarakat (STBM). Selain itu, pemerintah kota harus mempunyai kebijakan yang jelas terhadap penyediaan sumber air bersih yang layak pada penduduk di pemukiman kumuh.

\section{Ucapan Terimakasih}

Penelitian ini merupakan bagian dari penelitian dengan judul "Risk Assessment on Watersource and Drinking Water Quality of Urban Slum Area in Cikapundung River Basin in Bandung Municipality"yang didanai oleh Kemenristekdikti melalui Hibah Kerjasama Luar Negeri. Peneliti mengucapkan terima kasih atas kerjasama tim surveyor dari Dinas Kesehatan Kota Bandung 
dan segenap kader kesehatan di Kelurahan Tamansari serta tim analis di Laboratorium Mikrobiologi dan Parasitologi FK Unpad yang telah membantu pelaksanaan penelitian ini.

\section{Daftar Pustaka}

1. Shaheed A, Orgill J, Montgomery MA, Jeuland MA, Brown J. Why "improved" water sources are not always safe. Bull WHO. 2014; 92(1):283-9.

2. Bain R, Cronk R, Hossain R, Bonjour S, Onda K, Wright J, dkk. Global assessment of exposure to faecal contamination through drinking water based on a systematic review. Trop Med Int Health. 2014;19(8):917-27.

3. Sirus HS, Narain HP, Ferry W, Dazwir N, Sri PP, Ainur R, dkk. Diarrhoea episodes and treatment-seeking behavior in a slum area of North Jakarta, Indonesia. J Health Popul Nutr. 2006;22(2):119-29.

4. Laura CS, Mayur MD, Kathleen MM, Menachem E. Relationship between use water from community-scale water treatment refill kiosks and childhood diarrhea in Jakarta. Am J Trop Med Hyg. 2012;87(6):979-84.

5. Dinas Kesehatan Kota Bandung. Profil Kesehatan Kota Bandung. Bandung: Dinas Kesehatan Kota Bandung; 2013.

6. Badan Pusat Statistik. Laporan Informasi Administrasi Pemerintah Daerah Kota Bandung. Bandung: Badan Pusat Statistik; 2012.

7. Semba RD, Kraemer K, Kai S, Saskia $\mathrm{PD}$, Akhter N, Moench-Pfanner R, dkk. Relationship of the presence of a household improved latrine with diarrhea and underfive child mortality in Indonesia. Am J Trop Med Hyg. 2011;84(3):443-50.

8. Daniel E, Montano DK. Theory of reasoned action, theory of planned behavior and the integrated behavioral model. Dalam: Karen Glanz BKR, Viswanath K, penyunting. Health behavior and health education theory, research and practice. Edisi ke-4. San Francisco: John Wiley and Sons; 2008. hlm. 67-92.

9. Benjamin FA, John MC. Treating water with chlorine at point of use to improve water quality and reduce child diarrhea in developing countries: a systematic review and meta-analysis. Am J Trop Med Hyg. 2007;76(2):354-64.
10. Allegranzi B, Pittet D. Role of hand hygiene in healthcare-associated infection prevention. J Hospital Infect. 2009;73(4):305-15.

11. Williams HA, Gaines J, Patrick M, Berendes D, Fitter D, Handzel T. Perceptions of health communication, water treatment and sanitation in Artibonite Department, Haiti, March-April 2012. PLoS ONE. 2015; 10(11):1-17.

12. Hulland KRS, Leontsini E, Dreibelbis R, Unicomb L, Afroz A, Dutta NC, dkk. Designing a handwashing station for infrastructurerestricted communities in Bangladesh using the integrated behavioural model for water, sanitation and hygiene interventions (IBMWASH). BMC Public Heath. 2013;13(1):87789.

13. Samir VS, Menon M, Trivedi K, Ati A, Figueroa ME, Ainslie R, dkk. Microbiologic effectiveness of boilling and safe water storage in South Sulawesi, Indonesia. J Water Health. 2011;9(3):577-85.

14. Ameer S, Jennifer O, Maggie AM, Marc AJ, Joe B. Why improved water sources are not always safe. Bull WHO. 2014;92(1):283-9.

15. Hamoudi A, Jeuland M, Lombardo S, Patil S, Pattanayak SK, Rai S. The effect of water quality testing on household behavior evidence from an experiment in rural India. Am J Trop Med Hyg. 2012;87(1):18-22.

16. Akoachere JF, Omam LA, Massalla TN. Assessment of the relationship between bacteriological quality of dug-wells, hygiene behaviour and well characteristics in two cholera endemic localities in Douala, Cameroon. BMC Public Health. 2013;13(1):692-706.

17. Davis J, Pickering AJ, Rogers K, Mamuya S, Boehm AB. The effects of informational interventions on household water management, hygiene behaviors, stored drinking water quality, and hand contamination in peri-urban Tanzania. Am J Trop Med Hyg. 2011;84(2):184-91.

18. Timothy D, Rose A, Eric L, James GK, Mary AS, Tania D. A qualitative assessment of beliefs, attitudes, and behaviors related to diarrhea and water fitration in Rural Kenya. Am J Public Health. 2011;101(8):1515-20.

19. Ayotunde TE, Tunde OE, Gregory OA, Kannan K, Saravanadevi S, Satish RW. Prioritizing hazardous pollutants in two Nigerian water supply schemes: a risk-based approach. Bull WHO. 2013;91(1):553-61. 